\title{
Post-Soviet Heritages in the Making
}

Gertjan Plets

HCM 7: 1080-1088

DOI: $10.18352 / \mathrm{hcm} .600$

\begin{abstract}
Despite the growing interest in post-Soviet space (the countries formerly located in the Soviet Union or its sphere of influence) in the field of memory studies, researchers have only just begun to the study how 'things and practices' from the past are mobilized, institutionalized and repackaged in this particular part of the world. This special collection explores how heritage is being made in a highly diverse and multicultural space where Soviet modernist conceptions of culture and identity interact with local deeply rooted attitudes as well as post-Soviet economic and political challenges.
\end{abstract}

Keywords: heritage politics, historical culture, memory, postsocialism, Soviet Union

\section{Introduction}

Over the past three decades, as a result of critical engagements both with the socio-political intricacies involving the historical discipline ${ }^{\mathrm{I}}$ and the influence of nationalism on the construction of museums, ${ }^{2}$ traditional understandings to cultural heritage have been challenged. While positivist, universalist discourses, in which heritage is reified as an objective material inheritance of the past, still reverberate and dominate many official heritage policies and bureaucratic practices, ${ }^{3}$ in the allied fields of archaeology, anthropology, history and conservation studies heritage is now studied through a more critical lens. ${ }^{4}$ Not only are 'intangible' customs, practices and traditions also considered 
to be heritage,, 5 but not less importantly, heritage is now widely seen as a socio-cultural construct, inherently selective and mediated through a complex web of power relations and deeply rooted epistemic structures.

Clearly, something from the past is not heritage just because it has been inherited from the past, but because it embodies values and meanings that are believed to be important in the present. Heritage is concerned with memory and socio-cultural values; heritage does not define itself: it is the result of a social action through which dimensions of the past are valued and remembered. ${ }^{6}$ As Smith puts it, heritage is the outcome of an act of meaning making and commodification. ${ }^{7}$ Something is not heritage but rather becomes heritage when people attach values to it. These values are not universal but individually held; they are contextdependent and a reflection of what groups of people appraise or repudiate in the present or the future; and they are inextricably linked with their identity. Attaching values to 'things' from the past is the result of a social practice and thus needs to be conceived sociologically and semiotically. This does not mean that heritage is entirely intangible, since the 'thingness' of heritage and the affordances encoded in the materiality of old buildings and sites also influences the way people construct the material past. The valuation process through which things become heritage trigger feelings and emotions, and feed into a sense of commitment or belonging. Values reflect consensual injunctions, sensitivities and socio-cultural meanings. They relate to the epistemological framework of the agents and the specific social arena in which these operate. ${ }^{8}$

In his Cosmologies in the Making: A Generative Approach to Cultural Variation in Inner New Guinea (1987), Fredrik Barth explored the variations in cosmological traditions and rites amongst adjacent communities of the Melanesian Ok people. Interestingly, these communities, which shared a similar language, material culture and ecological systems, demonstrated striking differences (some hardly reconcilable) in their communal rites and ceremonies. ${ }^{9}$ Breaking with traditional anthropological theory regarding culture and tradition, Barth argued that culture is constantly reproduced and consequently undergoes continual change. Based on his comparative research, Barth explained variations through differences in human agency and creativity, which themselves spring from an interplay with the social arena. ${ }^{10}$

Following Barth's argument concerning cultural change and sociocultural expression, I suggest that heritage, too, is constantly in the 
making, as a result of the highly dynamic interplay between human agency, the agency of the heritage object or practice, and social context in which they occur. Thus, as with any social practice, change is inevitable, presenting heritage practitioners with a paradox to respond to both the heritage of the future and the future of what is now considered heritage. What is remembered by a group today may have lost its meaning in twenty years. What is not important today can become central in the identity politics of subsequent generations.

Heritage is continuously made and remade through the historically evolving field conditions that define a socio-cultural arena and its interplay with deeply rooted dispositions, ${ }^{11}$ power relations ${ }^{12}$ and the materiality of objects and practices. ${ }^{13}$ If we want to disentangle this Gordian knot of interrelations, methodologies and sources and understand the making of heritage over time in a specific context, we need to combine approaches from history, anthropology, archaeology and political science. Over the past three decades scholars in the field of heritage studies have embarked on a quest to explore heritage making beyond Europe, which has traditionally been the focal point. However, despite the growing interest in post-Soviet space (the countries formerly located in the Soviet Union or its sphere of influence) in the field of memory studies, ${ }^{14}$ researchers have only just begun to the study how 'things and practices' from the past are mobilized, institutionalized and repackaged in this particular part of the world. ${ }^{15}$ This special collection seeks to contribute to this development by exploring how heritage is being made in a highly diverse and multicultural space where Soviet modernist conceptions of culture and identity interact with local deeply rooted attitudes as well as post-Soviet economic and political challenges.

\section{Tsarist and Soviet Modernity: the Construction of Identity and Heritage}

Although heritage valuation is mediated locally, this does not mean that there are no dominant approaches and conceptions influencing our engagement with the past: contemporary engagements are structured by dominant heritage discourses that have evolved historically. The proliferation of specific ways of engaging with tangible and intangible 
expressions of the past has often been connected to the dyad modernity and nationalism. The professionalization of the study of the past, the need to scientifically classify and preserve objects from that past, ${ }^{16}$ and the urge to find markers of identity that subdivided people into ethnic groups, ${ }^{17}$ all ensured that since the nineteenth century specific heritage discourses became embedded in the cultural polities of many Western nations. This Western engagement with heritage, centring around monumentality, materiality and scientific expertise, has created a dominant way of engaging with the material legacy of the past that still defines contemporary engagements and that has 'colonized' the globe through a suite of international frameworks, most importantly UNESCO's I972 World Heritage Convention. ${ }^{18}$

However, there are limits to these critical appraisals of the impact of this dominant Western heritage discourse, since it creates the impression that the periphery is a mere passive recipient. Explorations into modernity globally, and Russia and its borderlands specifically, have encouraged us to see modernity and modernization as something more gradual and multiple, in part because it is always mediated locally. ${ }^{19}$ For heritage this means that, from a global perspective, multiple dominant heritage discourses have gradually evolved over the past, texturing contemporary heritage making practices.

Although analyses of modernity in the territories of the former Soviet Union have often centred on science and economic production, a small number of studies have explored how modern norms and ideas were applied to history and identity. Already during Tsarist times museums were created to scientifically order the past, ${ }^{20}$ and excavations were sponsored to raise national awareness. ${ }^{21}$ These early engagements were continued in the Soviet period, and the material past was placed at the heart of identity building efforts. Material culture was mobilized as one of the key determinants in designing the maps, census and museums to create an empire consisting of manageable nationalities. ${ }^{22}$ As was the case in Western Europe, aesthetics, scientific expertise and monumentality were foregrounded in the engagement with the past. But even more than in the West, the importance of material culture for designating ethnic groups stood centre stage. Ethnic identity was (and still is) a major issue in the vast space the Soviet Union inherited from the Tsarist Empire, since hundreds of ethnic groups and minorities define the cultural geography of the region. The specific way heritage was 
instrumentalized ensured that the dominant heritage discourse in the Soviet Union has been focused primarily on ethnicity, making it subtly different from heritage discourse in Western Europe. When the Soviet Union started to show its first cracks, heritage was similarly mediated in ethnic terms to legitimize special cultural rights and sovereignties. ${ }^{23}$

The articles in this specials issue critically explore how heritage has been made and remade in the former Soviet bloc. Each article focuses on one key case study and explores how specific local attitudes interact with Soviet norms and conceptions of history. The various contributions look at very different national contexts and explore different types of heritage, they all examine the role of history and material legacy in celebrating and contesting identities. Central to each case study is the question of how Soviet ideas about group membership and the importance of ethnic inheritance have coalesced with post-Soviet realities and challenges.

In 'The Cost of Memorializing: Analyzing Armenian Genocide Memorials and Commemorations in the Republic of Armenia and in the Diaspora', Sabrina Papazian explores how Armenian ethnic communities deal with traumatic experiences, in particular the different ways in which the Armenian genocide is remembered in Armenia as compared to Armenian diasporas in France and the United states. Soviet interpretations of history and the concomitant memorial practices that identified Armenia as an ethnic homeland, have ensured that today Armenian citizens engage differently with the genocide from Armenians forced to relocate after the genocide. This underscores that Soviet cultural politics have had a deep impact on the ways specific pasts have been given form in memory and heritage. At the same time, the diaspora groups today influence cultural life in Armenia, showing that post-Soviet memory cultures are being reshaped by intercultural exchange in a globalized world.

Oksana Myshlovska, in 'Delegitimizing the Communist Past and Building a New Sense of Community: the Politics of Transitional Justice and Memory in Ukraine', examines the politics of history in contemporary Ukraine. Here history and language, as in the Soviet period, remain important markers of ethnic identity and present themselves as unique instruments to 'other' Ukraine from Russia. However, as different groups and parties have struggled for control of Ukraine over the past two decades, history has been at the crux of Ukrainian nation building. Myshlovska draws attention to how Soviet history is being retold today. This applies especially to World War II: the memory 
culture of the 'Great Patriotic War' is perhaps one of the most politically charged legacies inherited from the Soviet Union, one that is difficult to deal with in a changing political landscape where Russia and the West battle over influence in Ukraine.

The role of food in processes of remembering and constructing identities is the theme of Irina Perianova's "'Something Borrowed, Something New": Memory and Oblivion in Food Discourse in PostSoviet Eastern Europe'. The article draws attention to the importance of an often-overlooked type of heritage: culinary heritage. Through her theoretical reflection on the importance of food products and ingredients Perianova underlines that food is not a passive cultural expression handed over from the past, but a socio-cultural practice that can serve as a commentary on geopolitical developments (such as the refusal to buy Ukrainian products in Russia today) and involves a process of meaning making through which ethnic identities are negotiated.

Finally, in 'The Patarei Sea Fort: Perspectives on Heritage, Memory, and Identity Politics in Post-Soviet Estonia', Onessa Novak and Gertjan Plets explore the discourses around the Patarei Sea Fort, a former Nazi and Soviet prison that has become a 'dark heritage site'. Ethnic differences rooted in the Soviet Union have defined cultural politics in Estonia since it became an independent nation during the I99os. However, the legacy of the Soviet Union itself remains difficult to deal with, especially since the 'occupation' by the Soviet Union is interpreted as a Russian takeover of Estonia. This is problematic since in addition to the Estonian majority there is a large but marginalized ethnic minority of Russian descent in Estonia today. Dealing with the Soviet past is incredibly difficult, and can undermine attempts to cultivate a shared sense of Estonian citizenship across the Russian-Estonian ethnic divide. However, after years of ignoring the Soviet past, the Estonian state and conservative NGOs have started to politicize it, in order to vilify the Russian neighbour and underscore that the right future for all Estonia's citizens is a European one. However, this does not mean that dark heritage sites such as Patarei immediately become instrumentalized by the Estonian state. While large Soviet structures such as the prison have symbolic value, large industrial-looking buildings have increasingly gained economic value, since they can be used to gentrify entire neighbourhoods. In the case of Patarei, economic value seems to trump culture and politics. 


\section{Notes}

I Berber Bevernage, 'State-Sponsored History after I945: An Introduction', Berber Bevernage and Nico Wouters (eds), The Palgrave Handbook of State-sponsored History After 1945 (London, 2018); Claude Lévi-Strauss, The Savage Mind (Chicago IL, I966).

2 Benedict Anderson, Imagined Communities (London, 2006); Tony Bennett, The Birth of the Museum: History, Theory, Politics (London, I995).

3 Lynn Meskell, A Future in Ruins: UNESCO, World Heritage, and the Dream of Peace (Oxford, 2018); Gertjan Plets, 'Heritage Bureaucracies and the Modern Nation-State: Towards an Ethnography of Archaeological Systems of Government', Archaeological Dialogues 23:2 (2016) I93-2 I3.

4 Sharon Macdonald, Memorylands: Heritage and Identity in Europe Today (Abingdon, 2013).

5 Laurajane Smith and Natsuko Akagawa, Intangible Heritage (Abingdon, 2008).

6 Denis Byrne, 'Heritage as Social Action', Graham Fairclough, Rodney Harrison, James Jameson and John Schofield (eds), The Heritage Reader (New York, 2008); Rodney Harrison, Heritage: Critical Approaches (Oxon, 2012).

7 Laurajane Smith, Uses of Heritage (London, 2006).

8 John Schofield, 'Heritage Management, Theory and Practice', Graham Fairclough, Rodney Harrison, James Jameson and John Schofield (eds), The Heritage Reader (New York, 2008).

9 Frederick Barth, Cosmologies in the Making: A Generative Approach to Cultural Variation in Inner Guinea. Cambridge (Cambridge, I987).

Io Barth, Cosmologies in the Making, 74-82.

I I Pierre Bourdieu, The Logic of Practice (Stanford CA, I980).

I2 Michel Foucault, 'Governmentality', Graham Burchell, Colin Gordon, and Peter Miller (eds), The Foucault Effect: Studies in Governmentality (Chicago IL, I99I).

I3 Alfred Gell, Art and Agency: An Anthropological Theory (Oxford, I998).

I4 Alexander Etkind, Warped Mourning: Stories of the Undead in the Land of the Unburied (Stanford CA, 20I3); Maria Mälksoo, 'The Memory Politcs of Becoming European: The East European Subalterns and the Collective Memory of Europe' European Journal of International Relations I5:4 (2009) 653-80.; Stephen Norris, 'Memory for Sale: Victory Day 20 I0 
and Russian Remembrance', The Soviet and Post-Soviet Review 38 (20 I I) 20 I-29.

I5 Julie Deschepper, 'Between Future and Eternity: A Soviet Conception of Heritage', International Journal of Heritage studies 26:5 (2018) 49I-506; Gertjan Plets, Nikita Konstantinov, Vasilii Soenov and Erick Robinson, 'Repatriation, Doxa, and Contested Heritages', Anthropology \& Archaeology of Eurasia 52:2 (20I3) 73-98.

I6 Julian Thomas, Archaeology and Modernity (Abingdon, 2004).

I7 Thomas Hylland Eriksen, Ethnicity and Nationalism: Anthropological Perspectives (London, I993).

I 8 Harrison, Heritage Critical Approaches; Smith, Uses of Heritage, where the dominant approach is called Authorised Heritage Discourse.

I9 Dilip Goankar, Alternative Modernities (Durham NC, 200I); Stephen Kotkin, Magnetic Mountain: Stalinism as a Civilization (Berkley CA, I997).

20 Katia Dianina, 'The Return of History: Museum, Heritage, and National Identity in Imperial Russia', Journal of Eurasian Studies I: I (20 Io) I I I-8.

2 I Mara Kozelsky, 'Ruins into Relics: The Monument to Saint Vladimir on the Excavations of Chersonesos, I827-57', The Russian Review 63 (2004) 665-72.

22 Francine Hirsch, Empire of Nations: Ethnographic Knowledge and the Making of the Soviet Union (Ithaca NY, 2005).

23 Victor Shnirelman, Who Gets the Past? Competition for Ancestors among Non-Russian Intellectuals in Russia (New York NY, I996).; Valery Tishkov, Ethnicity, Nationalism and Conflict in and after the Soviet Union: The Mind Aflame (London, I997).

\section{About the Author}

Gertjan Plets is an anthropological archaeologist based at Utrecht University, the Netherlands, and specialized in corporate heritage funding and indigenous cultural heritage politics. Since 2009 he has been working in the Altai Republic tracing the impact of Gazprom's corporate social responsibility programmes on local cultural politics and cultural heritage preservation initiatives. Gertjan was previously based at Stanford University, where he researched the role of cultural heritage 
in global politics. Plets has published on a variety of topics related to heritage and memory politics in Siberia, the World Heritage politics of the Russian Government, and the Russian funding of heritage preservation in the Middle East as a tool of soft power. His research areas have focused on heritage ethics, cultural landscapes, memory politics, cultural history and resource development. 